\title{
"Alíngua desse povo não tem osso, deix'esse povo falá": campo sonoro da linha de Quimbanda do Terreiro de Umbanda Reino de Luz - som e preconceito
}

\author{
Renata Schmidt de Arruda Gomes (Pelota-RS) \\ ren_sagom@hotmail.com
}

\begin{abstract}
Resumo:A Umbanda é uma religião afro-brasileira e, tal como é praticada no Reino de Luz, é essencialmente sonora. A religião umbandista é muito estigmatizada por ser relacionada, por alguns não adeptos a Umbanda, às práticas do "mal", magia negra e culto ao diabo. Muitas são as diferenças entre as concepções religiosas e de mundo entre adeptos da Umbanda e de outras religiões, estas diferenças provocam choques de crenças e, muitas vezes, geram preconceitos. Neste trabalho, proponho analisar a cosmo visão umbandista através dos Pontos cantados e práticas sonoras em geral, dos discursos dos participantes do Terreiro de Umbanda Reino de Luz e seus principais pontos de atrito com visões do senso comum. Acredito que através da análise dos sons presentes nesse ambiente, aliados aos discursos dos membros da terreira, possamos melhor entender os preconceitos existentes em relação a esta religião e suas tentativas de adaptação para melhor aceitação social.
\end{abstract}

Palavras-chave: Música, Umbanda, Etnomusicologia.

Sound field "linha de Quimbanda" of "Terreiro de Umbanda Reino de Luz": sound and prejudice

Abstract: The Umbanda is an afro-Brazilian religion and, as it is practiced in the Reino de Luz, is essentially sonorous. This religion suffers much prejudice for being related, for some not adepts, to the practical of the "evil", cultured black magic and to the devil. Many are the differences between the religious and world conceptions between adepts of the Umbanda and of other religions; these differences provoke shocks of beliefs and, many times, generate preconceptions. In this work, I consider to analyze the umbandistaCosmo vision through the practical of "Pontos Cantados" (typical religious songs), through sonorous practices, through the speeches of the participants of aspecific religious group, called "Terreiro de UmbandaReino de Luz", working with its main points of attrition in opposite of the visions of the common sense. I believe that through the analysis of the sounds of this environment, allied to the speeches of the members of the "terreira" (the religious group", let us better understand the existing preconceptions in relation to this religion and its attempts of adaptation for better social acceptance.

Keywords: Music, Umbanda, Ethnomusicology. 


\section{1- Abrindo os trabalhos - introdução}

Este trabalho tem origem em uma pesquisa de mestrado realizada na linha de etnografia das práticas musicais do Programa de Pós-Graduação da UFRJ. Esta se propunha a estudar o campo sonoro - no decorrer do texto explico o porquê da utilização deste termo para designar as práticas sonoras do ambiente em questão - do Terreiro de Umbanda Reino de Luz.Importante ressaltar que sou uma pesquisadora nativa, já que faço parte da terreira ${ }^{1}$ estudada.

Essa religião, tal como é feita na terreira acima citada, é essencialmente sonora. Cada parte do ritual religioso possui Pontos (cânticos) - tocados por atabaque, canto e palmas - especificos e, é através destes que as entidades (espiritos da Umbanda) descem à terra.Esses Pontos cantados poderiam ser chamados de "a música da terreira".

De acordo com o adiantar da pesquisa, pude notar que para um melhor entendimento do ambiente estudado seria necessário considerar outros aspectos além destes que normalmente são chamados de "música". Para tal utilizei o termo campo sonoro. Essa escolha se deu, também, a fim de tentar seguir as novas tendências da etnomusicologia atual. Hoje, dentro dos estudos etnomusicológicos, buscase compreender não só a música - como uma categoria a parte -, suas funções e importância em algum ambiente específico, mas, além disso, todos os sons que formam esse ambiente. Deste modo, além dos sons das palmas, atabaques e canto que fazem parte das práticas do Reino de Luz, outras caracteristicas foram importantes para a formação do campo sonoro deste ambiente, como: o som dos sinos, falas e emissões das entidades durante os rituais,alémdos discursos dos membros da corrente ${ }^{2}-$ expostos durante conversas e entrevistas - e o presente nas letras dos pontos cantados, enfim, todos os sons que formam a terreira.

Desde o início das pesquisas, o fato de grande parte dos integrantes da casa ${ }^{3}$ terem sofrido algum de tipo de preconceito chamou minha atenção e despertou em mim a vontade de saber o motivo pelo qual isso ocorria. Assim, após alguns membros do Reino de Luz terem sinalizado a vontade de mudar as letras dos Pontos cantados da linha de Quimbanda devido ao conteúdo dessas não os agradarem e, segundo eles, não corresponderem às práticas da casa, decidi estudar a relação som-preconceito.

0 estudo de uma prática sonora dentro de seu contexto já é um ponto pacífico dentro da etnomusicologia,mas neste contexto específico do Reino de Luz, vi que para melhor entender essas práticas seria importante compreender também o ambiente ao redor da terreira. Neste trabalho, proponho analisar a cosmo visão umbandista através dos Pontos cantados e práticas sonoras em geral, dos discursos dos participantes do Terreiro de Umbanda Reino de Luz e seus principais pontos de atrito com visões do senso comum. Acredito que através desta análise possamos melhor entender os preconceitos relativos a esta religião e aos seus adeptos.

\section{2 - Sobre as crenças e práticas do Reino de Luz}

A prática religiosa umbandista se dá através de linhas, - grupos de espíritos como: preto-velho, caboclo, Exu dentro das linhas de Umbanda a mais estigmatizada é a de Quimbanda - linha de Exu, Pomba-Gira e Zé Pelintra - exatamente pela ligação que se faz da figura do Exu à do diabo e, por consequência, a tudo que está relacionado ao diabo (já que este é visto como o grande mal).

Esta linha é festejada dentro da casa uma vez por mês, em rituais que se chamam Festa de Quimbanda, o uso do termo festa não se dá por acaso, já que o Povo de Quimbanda é quem cuida de seus cavalos diariamente, por ser o Povo mais próximo de nós seres humano. São eles que fazem o trabalho sujo, isto é, limpam as energias negativas, afastam estas dos umbandistas e os protegem de qualquer tipo de "mal". Por este motivo, uma vez por mês se faz uma Festa para essas entidades, a fim de homenageá-las e fortificá-las, através do ritual, que inclui, além do toque ${ }^{5}$ do tambor, canto e palmas, bebidas, comidas e presentes. Existe um ponto cantado desta linha que acredito ilustrar a relação que os umbandistas têm com essas entidades (Ex.1).

As Quimbandas - como são também chamados esses rituais - são fechadas, só podem participar dos trabalhos os membros da corrente e convidados previamente autorizados pelo Cacique. Isto ocorre, poisse acredita que, sendo os Exus, Pomba-Giras e Zé Pelintras, os protetores da terreira, não é aconselhável que muitas pessoas de fora estejam presentes.

Chegarmos numa Festa de Quimbanda é diferente de chegar a um trabalho de Umbanda, primeiramente, pois as primeiras acontecem da meia-noite às quatro horas da manhã. Outra grande diferença diz respeito às roupas dos médiuns, na Umbanda todos se vestem de branco, os homens de calça e camiseta e as mulheres de saia rodada e camiseta; na Quimbanda todos estão vestidos de preto, preto e vermelho, preto e branco, roxo e combinações destas cores.

Antes dos trabalhos iniciarem-se as lâmpadas são trocadas por lâmpadas vermelhas e a penumbra se instala no ambiente, bebidas, comidas, charutos, cigarros, cigarrilhas, capas, cartolas, chapéus e presentes são preparados para que assim que as entidades cheguem $\dot{a}$ terra estes sejam entregues a elas. Sente-se uma pequena euforia no ar, os trabalhos acontecem somente uma vez por mês e muitos médiuns aguardam ansiosamente 0 momento de homenagear aqueles que tantos os ajudam.

A corrente se forma, homens à esquerda e mulheres a direita do Congá. Neste momento podemos ver sorrisos e olhos apreensivos, tanto entre os médiuns quanto entre as poucas pessoas que compõem a assistência. Assim que todos estão prontos e dentro da corrente, começa o ponto de cruzar a linha - este é o único ponto de abertura da Quimbanda (Ex.2). 


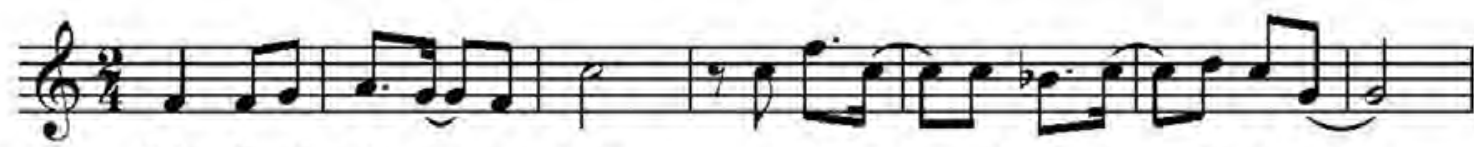

Năo fa-ço mal a_min-guém pro-cu-ro__ não ter $\mathrm{i}$ - mi-mi-gos —
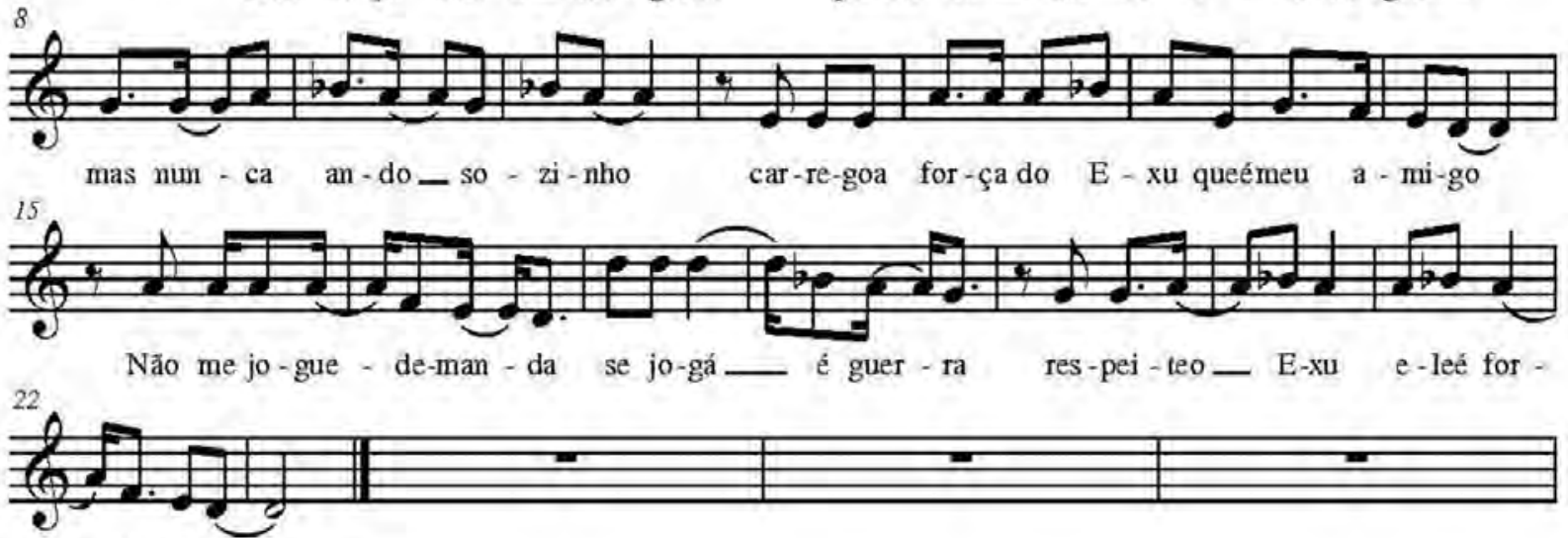

ça, ter-ra

Ex.1 - Ponto de Exu recolhido no Terreiro de Umbanda Reino de Luz.

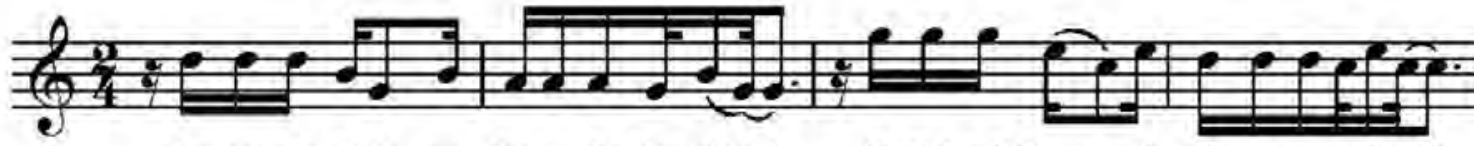

Eu cru-zoa linha na ho-ra de Xan-gô-ô-ô Oi Sal-yeo-Xum = O-xós-sias-so-vi-ô-ô-ô

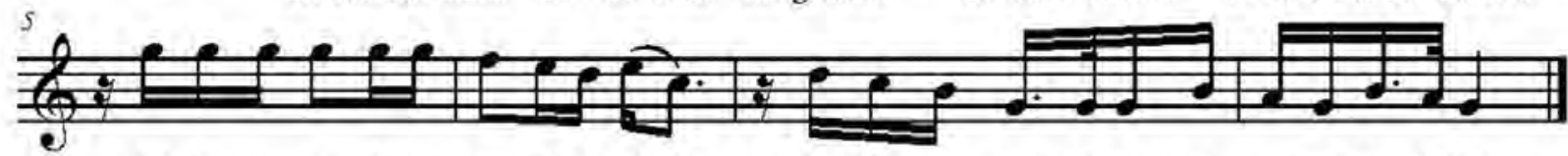

Sal-v'Ie-man-já I-an - ça já-che-gô o Con-fir-maos pre-tơueo E - xu vai tra-bałhá

Ex.2 - Ponto de Cruzamento da Casa, ponto utilizado para a abertura dos trabalhos de Quimbanda.

Juntamente com o início deste ponto, além do toque dotambor, podemos ouvir as palmas e os sinos, confirmando assim o início dos trabalhos. Após este ponto canta-se, geralmente, um ponto de Lúcifer, Dono da Quimbanda, que é quando esta entidade chega à terreira, caso seu cavalo (médium) esteja presente, e, após este, o ponto do Exu Caveira, chefe da casa, que é quando este chega à Quimbanda.

Logo após iniciam outros pontos, à medida que os médiuns vão recebendo suas entidades; os cambonos ${ }^{6}$ os vestem com suas capas, cartolas e demais objetos rituais. Podemos ouvir além dos tambores e cantos, risadas roucas, sons guturais que nos avisam que os Exus estão chegando. As primeiras duas horas da Festa são dedicadas aos Exus, homens e mulheres recebem estas entidades que dançam, bebem e conversam com os membros da corrente que não estão incorporados e com as pessoas da assistência. Neste momento podemos ver um bailar de longas capas negras ou vermelhas (em sua maioria), rostos sérios, pois os Exus são assim, além de abundante marafa - cachaça - bebida de quase todos os Exus.

Passadas as duas primeiras horas da Quimbanda, as mulheres vão se trocar, colocar seus vestidos, maquiagens, brincos, pulseiras e perfumes para receberem suas Pomba-Giras. Os homens que têm Zé Pelintra deixam de trabalhar com seus Exus e passam a trabalhar com os Zé's. Alguns homens também recebem Pomba-Gira assim como algumas mulheres recebem Zé Pelintra. A partir de então podemos ouvir grandes gargalhadas, sabe-se então que as mulheres - Pomba-Giras - estão chegando. Vemos vestidos, cigarrilhas, champanhe ou cidra - que são as bebidas mais comuns para as Pomba-Giras. Algumas dançando, outras encostadas nas paredes conversando com algum Zé Pelintra. Estas são ameaçadoras, um olhar 
atravessado de uma delas estremece qualquer um, não que elas vão fazer alguma coisa, mas simplesmente 0 fato de nos olharem significa que sabem nossos maiores segredos e, a qualquer momento, podem vir nos falar, em meio a risadas, coisas que não queremos ouvir.

Os Zé's, como são carinhosamente chamados, são uma "festa", chegam gingando, com toda a sua malandragem, ternos brancos, bengala, chapéu de palha, fumando, tomando cerveja ou batidas de coco. Eles exaltam o mundo do ócio, mas estão sempre prontos para trabalhar em prol dos seus filhos.

A música não para, o tambor nunca pode parar de tocar, pois é este o responsável por manter a energia elevada. As Quimbandas são trabalhos mais pesados dos que os de Umbanda, pois lidam com energias mais pesadas, transformando energias negativas em positivas, por este motivo o toque do tambor e canto torna-se tão importante e indispensável. Estas energias (do cavalo e ambiente) são consideradas mais pesadas, pois são aquelas mais humanizadas, já que as entidades de Quimbanda são consideradas as mais próximas dos seres humanos, estas são capaz de transformar as energias mais pesadas em energia positiva.

0 toque de Quimbanda é bastante diferente do toque de Umbanda e pode ser facilmente reconhecido ao escutálo. Deste modo, a audição deste toque passa a ser um modo de caracterizar, por parte de outros umbandistas e até de não adeptos, as terreiras Quimbandeiras.

\section{3 - Abrindo um parêntese - discutindo o preconceito}

Acredito que parte do preconceito existente em relação à Umbanda, aconteça pela ligação que se faz da figura do Exu ao diabo. Por outro lado, com o passar do trabalho de campo, fui "descobrindo" outras características presentes na linha de Quimbanda que se diferenciam bastante da visão de mundo, como senso-comum, dos não adeptos à Umbanda ${ }^{7}$, o que me levou a refletir sobre as diferenças existentes na nossa sociedade ${ }^{8} \mathrm{e}$ a constante disputa por espaço dentro desta.

Ataques feitos por pessoas provenientes de religiões Neopentecostais contra a Umbanda, preconceitos e discriminações sofridos pelos umbandistas, preconceitos e discriminações realizados por nós umbandistas, diferentes visões de mundo, diversidade de crenças e fé, tudo isso configura o grupo de pessoas que formam um grupo social e as disputas por espaço e legitimações são frequentes neste contexto. Deste modo, acredito não poder tratar de preconceito e discriminação, sem levar em conta que uma das maneiras de legitimar práticas e crenças é atacando e destituindo de crédito as outras práticas e crenças.

Coloco a questão em discussão não para diminuir as experiências sofridas pelos membros do Reino de Luz, mas no sentido de não supervalorizá-las, pois como acredita Lom - Cacique ${ }^{9}$ do Reino de Luz -,o preconceito está em tudo:

Lom - "Sem dúvida nenhuma. 0 preconceito está enraizado em tudo, no homossexualismo, no... na mulher que se veste um pouco mais ousado, na mulher que se veste mal, no homem que é gordo, na mulher que é gorda, na mulher que é anoréxica, preconceito tem Em tudo." (Em entrevista a autora, 27/04/2008)

Apesar de concordar com isso, acredito ser importante discuti-lo e contextualizá-lo, a fim de tentar ver as possiveis causas de este ocorrer, no sentido de melhor entendermos os contextos nos quais ocorrem. No caso da Umbanda, uma religião que desde seu surgimento é muito estigmatizada, talvez seja possivel entender as mudanças ocorridas nas práticas religiosas levando em conta este estigma.

Durante minhas idas a campo, conversas e entrevistas busquei saber como os participantes da casa veem a questão acima exposta.

Acredito que diversas práticas umbandistas levam esta religião a ser estigmatizada, inclusive por esta estar constantemente relacionada às práticas do "mal" - ligadas as práticas de matança - e suas oferendas e entregas serem constantemente chamadas de macumbas, de modo pejorativo. Em dois momentos de sua entrevista Lauren conta como via a Umbanda antes de entrar para esta religião

Lauren - "Ah, eu tinha nove anos. A maior parte foi Kardecista, só que. dai a gente começou a conhecer pessoas, tipo vizinhas, entende? Que eram médiuns, mas eram médiuns de Umbanda. $\mathrm{E}$ aí a gente começou a... a.. a ir, pra vê como é que era, né. Pra.. a gente não tinha noção assim da.. da diferença, começô a ir. Acho que a minha mãe, assim como eu gosta da.. da vibração e tal, sei lá, da sensação de ta lá.. e aí a gente começô a ir. E.. Mas só que eu tinha muito medo de.. de Umbanda porque, Como Todo mundo, eu ligava, eu achava que Umbanda só tinha coisas ruins, que as pessoas trabalhavam é.. faziam coisas erradas e que aquilo tudo tinha um significado diferente do que tem. Não sei se tu entendeu o que eu quis dizê?" Eu - "Entendi.. negativo, tu tinha uma.." Lauren - "É, eu tinha uma ideia.. aquilo m'interessava, me chamada atenção, mas ao mesmo tempo era tipo assim, interessante e tal, mas não é legal de fazê."

Eu - "E tu acha que esse tipo de ligação, da.. do Exu com o diabo, essa imagem causa algum tipo de efeito pras pessoas que cultuam a Quimbanda, pra gente que cultua a Quimbanda?"

Lauren - "Ai.... Tipo.. pra mim no início, quando eu entrei, causava porque pra mim... eu achei que.. que fossem.. como é que eu vou dizê? Eu achei que só trabalhava com essas linhas quem quisesse fazê alguma coisa pro.. pro mal entende? Eu não sabia que tinha Exu e Pomba-Gira que.. que faziam.. que trabalhavam pro bem e que tem muitos que só.. que trabalham só pro bem, não tem? É que eu não sei muito bem da religião então.. eu tenho a minha "visão romântica", como diz o Diego, então.." (Em entrevista a autora, 28/04/08)

Assim como Lauren, muitas pessoas possuem visões parecidas sobre a Umbanda e Exu, o próprio Cacique do Reino de Luz, Lom, possuía visão semelhante antes de conhecer a religião. Segundo Ricardo Mariano

Na segunda metade do século XIX, a escravidão e o racismo incluindo o racismo científico - resultaram em franca perseguição 
religiosa ao candomblé e punição a seus seguidores. Em seguida, com o fim da escravidão e a queda em descrédito do racismo científico e seu corolário, o "baixo espiritismo", designação por meio da qual candomblé e umbanda foram sistematicamente desqualificados e rebaixados nos planos moral e religioso, foi mantido sob forte repressão institucional até a década de 1940. MARIANO (2007,p. 126-7)

\section{0 autor salienta que}

Ao lado disso, uma série de racionalizações religiosas de cunho cristão, de interesse institucional da Igreja Católica e há muito sedimentadas no imaginário social e na cultura brasileira, fundamentava concepções e juizos de valor para alicerçar e justificar as acusações de curandeirismo e de magia negra contra um sem-número de adeptos e líderes desses cultos. MARIANO (2007,p. 127)

Hoje, como o próprio Mariano chama atenção, a situação mudou, as religiões afro-brasileiras não são mais perseguidas pela polícia e nem são proibidas pelo estado ${ }^{10}$, mas mesmo assim "umbanda e candomblé prosseguiram sendo alvo de discriminação e, com menor frequência, até de atos de intolerância" MARIANO (2007,P. 128).

Rita Segato em "Racismo, discriminación y acciones afirmativas: herramientas conceptuales", trata do racismo, em suas diversas formas, expondo as diferentes esferas deste ato, diferenciando a discriminação do preconceito. A autora fala de "[...] três tipos de destinatários do preconceito e da discriminação racista": os que possuem etnicidade e raça, "[...] aqueles que conjugam uma diferença racial, um signo fenótipo, com um patrimônio cultural idiossincrático"; os que possuem raça sem etnicidade, "[...] aquelas pessoas que exibem traços raciais como cor de pele, tipo de cabelo, formato dos lábios e do nariz, etc., mas sem necessariamente serem portadoras de um patrimônio cultural diferenciado" e os que possuem etnicidade sem raça,

\section{[...] pessoas pertencentes a povos marcados pelo cultivo e transmissão de um patrimônio cultural idiossincrático e condutores de uma trama histórica que reconhecem como própria, mas que, devido a um antigo processo de mestiçagem, não necessariamente exibem traços raciais que as distinguem da população de sua região ou nação.SEGATTO (2007, P. 66-7) ${ }^{11}$}

Acredito que o caso da Umbanda, e mais intensamente da Quimbanda, seja o que Segato chama de etnicidade sem raça, pois, como já dito anteriormente, creio que as práticas umbandistas, mesmo possuindo elementos Kardecistas, Católicos, entre outros, são principalmente negras (me remeto às raízes africanas). Prandi possui visão semelhante:

Fragmentada em pequenos grupos, fragilizada pela ausência de algum tipo de organização ampla, tendo que carregar o peso do preconceito racial que se transfere do negro para a cultura negra, a religião dos orixás [Candomblé, Umbanda, etc.] tem poucas chances de se sair melhor na competição - desigual - com outras religiões.PRANDI (2004,p. 231)

Ao mesmo tempo é interessante ressaltar que em certo período dos estudos sobre religiões afro-brasileiras, a Umbanda não era considerada digna de estudos por não ser "pura", isto é, por 'não ser negra o suficiente' e, hoje, sofre preconceito e discriminações por ser 'negra demais'.

A linha de Quimbanda atenua esta "negritude" e, talvez também por isso seja a linha mais estigmatizada, além de ser um dos temas mais controversos da Umbanda, inclusive entre os próprios umbandistas de casas diferentes. As terreiras que se dizem Brancas ${ }^{12}$, são aquelas que não cultuam a linha de Exu, por acreditarem que estes são espíritos "atrasados e de pouca luz" ${ }^{13}$. Podemos ver então que as diversas visões em relação a esta linha estão presentes não somente entre umbandistas e não umbandistas, mas entre os umbandistas de diferentes casas e doutrinas $^{14}$.

Esta também é a linha que, geralmente, é representada negativamente e vinculada ao conceito de "mal": Exus, Pomba-Giras, são as entidades que mais comumente são ligadas à figura do diabo, logo esta é a linha mais "atacada" por não adeptos ou pessoas de outras religiões quando querem depreciar a Umbanda e suas práticas.

Creio que as visões negativas relacionadas à linha de Quimbanda sejam um dos (dentre os tantos) motivos pelos quais existem preconceitos em relação aos adeptos desta. Quando questionei aos membros da corrente da terreira se haviam sofrido algum tipo de preconceito ou discriminação, a maioria dos entrevistados respondeu-me que sim. Taize respondeu assim:

\footnotetext{
Taize - "Já, já..tranquilo assim, tinha uma.. eu trabalhava com uma.. uma menina, e aí ela... a gente conversava muito, assim, ela era minha colega de trabalho e ela.. enfim a gente vivia conversando sobre várias coisas e um dia entrou a religião. E ela era evangélica e ela... e ela foi e disse assim, ah, porque chegou um cara lá que ela conheceu e o cara era tri gente boa, mas ela ficou.. surpreendida porque ele era.. ele era de terrera, ela disse assim. E eu disse, "ué, mas não por isso, eu também sou". E ela ficou impressionada, porque ela disse assim: "ai, que estranho né? Tu é uma guria tão inteligente, uma guria que trabalha, estuda e é de terrera". E eu, "tá, mas o que tem a vê?" E ela, "ai, não, porque é estranho, né?". Tipo assim, coitada né? Deu pra vê que.. no mundo dela quem é de terrera é Burro e não pode fazê mais nada porque é de terrera. (risos) Mas foi, mas várias vezes, assim.. nos lugares, tu diz que é de terrera e as pessoas ficam te olhando atravessado... mas é isso ai!"

Eu - "É assim mesmo, né?"

Taize - "É, pior é que é." (Em entrevista a autora, 29/04/08)
}

Além de Taize, vários outros entrevistados já sofreram algum tipo de discriminação ou preconceito por serem umbandistas. Este tipo de situaçãoé relativamente comum. Podemos ver que, para algumas pessoas o fato de ser umbandista e "trabalhador" são coisas contraditórias. Lom perdeu parte de seus clientes por ser adepto a religião e Débora não pode se declarar pertencente à terreira para não perder parte de seus alunos de canto.

Segundo Lenny Alvarenga, "Ao contrário do que comumente se pensa a identificação exu-diabo não nasceu no Brasil, mas sim em terras africanas com 
os primeiros contatos dos missionários católicos e protestantes com as tradições religiosas locais". Segue o autor (citando Bouwen),

\begin{abstract}
Grosso modo, o culto a qualquer divindade apresentado pelos africanos, independentemente de quais fossem as suas características para os fiéis locais, foram tomados como o culto a divindades do mal (demônios, diabos, satã, etc.) pelos europeus de modo geral.ALVARENGA (2006, p.64)
\end{abstract}

Pode-se notar então que esta associação é mais antiga do que pensamos. Ao mesmo tempo, perguntei aos participantes da terreira o que eles pensavam sobre essa associação, porque motivo eles acreditavam que isto acontecia. As respostas foram reveladoras e levavam em conta muitos aspectos relativos às próprias práticas da Quimbanda. Taize me explicou a relação da figura do Exu ao diabo desta maneira,

Taize - "... eu vou falá por mim, assim.. quando eu entrei, eu me lembro que nessa primeira casa que eu te falei que eu ia, a.. eu achava esquisito quando eles chegavam, né, as luzes já... se apagavam e eles vestiam umas capas, ai tinha uns tridentes desenhados. E eu acho que, na verdade, a igreja Católica sempre pintô o demônio, o diabo, bem com esses trajes, capa, tridente, chapéu, colinha [rabinho] e tudo mais. E, acaba que até as imagens hoje que nós vamos comprá, dos nossos Exus, tem colinha [rabinho] e tem garfo, eu acho que um pouco é uma ligação, é um sincretismo que há com isso. De repente é por isso mesmo que as pessoas se confundem e eu não acho que seja uma..... uma confusão tão errada assim, porque, na verdade, infelizmente a.. a própria religião prega isso, tanto que as nossas imagens são moldadas dessa forma. Embora eu saiba que não é, até porque eu não acredito em diabo, demônio. Acho que existe energia ruim, mas.. não acredito que exista um.. uma figura que represente tudo isso. E... mas infelizmente a própria religião pinta os Exus dessa forma, então, na verdade, essa confusão que há.. principalmente pros negros, infelizmente não é tão errada assim, mas não que eu acredite que exista, até porque eu realmente não acredito." (Em entrevista a autora, 29/04/08)

Taize aponta para o fato de as representações simbólicas do Exu na Umbanda serem próximas às representações ao diabo ${ }^{15}$ feitas pela igreja católica e lamenta isso. Importante ressaltar que este modo de representar esta entidade não está presente somente nas imagens, roupas e adereços utilizados pelos médiuns quando os recebem, mas também nos pontos cantados desta linha de entidades.Estes pontos, em suas letras, descrevem Exu como quem "traz o seu garfo na mão"16, quem usa capa, vive na Calunga (cemitério), falam de catatumbas ${ }^{17}$, sangue, galo preto. Exu de duas cabeças, "uma é satanás no inferno e a outra Jesus de Nazaré"18. As Pomba-Giras aparecem como belas mulheres, Pomba-Gira Maria Quitéria "não mata porque não qué", Maria Padilha "é o que? Ela é o diabo!", elas "trabalha[m] com magia". Podemos ver então como essas descrições presentes nos pontos cantados acabam corroborando com as críticas sofridas pela Umbanda/Quimbanda, deste modo os pontos acabam reforçando essas imagens de ligação ao diabo, magia e morte. Este relacionamento com a morte, o cantar a morte, também é um ponto muito importante da cosmovisão umbandista, adiante me aterei a este.

Tornou-se interessante que, ao questionar aos participantes da terreira sobre a ligação destas duas figuras (Exu e diabo), os umbandistas se colocam no lugar do outro, destas pessoas que fazem tal ligação e, com isso, acabaram apontando diversos signos que, para o senso comum, isto é, para as "racionalizações religiosas de cunho cristão [...] há muito sedimentadas no imaginário social e na cultura brasileira" MARIANO (2007, p. 127), dizem respeito ao demônio e na Quimbanda faz parte da representação de Exu. Ao mesmo tempo, podemos notar que, algumas vezes, os signos religiosos que fornecem tal conexão, fazem sentido até para os próprios umbandistas, como, por exemplo, no depoimento de Zinho

\section{Eu - "E aquilo que eu tava falando, das pessoas ligarem os Exus ao diabo, porque tu acha que isso acontece? Porque as pessoas fazem essa ligação?"}

Zinho - "Eu acho que é porque.. pelas pessoas terem uma visão.. até porque se tu olha.. porque as pessoas tem uma visão do diabo que é vermelha e.. vamô supor, que o diabo é vermelho, olha um monte de gente de Exu, todo mundo de vermelho e preto, que que tu vai pensá? Numa encruzilhada, tomando sangue, que que tu vai pensá? É coisa do diabo! Não tem outra... até eu já pensei isso. Vi um monte de gente ali, na encruzilhada, o que eu vô fazê? É troço do inferno, né? Não tem mais o que pensá, acho que é por causa disso." (Em entrevista a autora, 01/05/08)

Vemos então que, muitas vezes, estas citadas representações, são tão fortes e presentes no meio em que vivemos que marcam os próprios umbandistas dentro de suas interpretações, formando um discurso dicotômico.

Além deste tipo de dicotomia presente no depoimento de Zinho, onde o próprio umbandista identifica elementos que remetem às noções de inferno e diabo presentes nas representações inicialmente Católicas destes e hoje já do senso comum, ainda existem visões relativas ao modo de ser das entidades de Quimbanda, como Guias que precisam de cuidado e ensinamentos. Podemos ver tal opinião no depoimento de Lucas, quando Ihes perguntei:

Eu - "Tu.. eu queria sabê como que tu vê, o povo, assim, de Quimbanda, de Exu, porque é o povo que eu vejo que, PombaGira, Exus, são os.. o povo mais controverso da religião. Eu queria saber como que tu vê esse povo?"

Lucas - "Ah, eu vejo assim, que é um povo assim óh, que além de sê difícil de lidá, também é um dos povos assim, mais, mais.. como é que eu posso dizê? Mais.. que a gente acaba se entregando também mais, um pouco mais e se apegando um pouco mais a eles, por eles serem mais próximos da gente. $\mathrm{E}$ a gente acaba se.. acaba se unindo mais a eles, entendeu? Eu vejo como um povo bem legal de trabalhá, só que é aquele detalhe, tu tens que sabê lidá com ele, tu tem... tu tem que tê tipo uma balança, tu tem que impor regras, se não fica bem difícil." Eu - "Porque?" Lucas - "Por causa que é um povo que.. é tipo.. é que nem uma criança, tu em que impor regras porque se não acaba tomando conta, sabe? Tu tem que falá o que é certo e o que é errado porque se não acaba te trazendo problemas.. é o meu modo de pensá." (Em entrevista a autora, 01/05/08)

É interessante este tipo de colocação como as de Lucas (além de Lucas, outros participantes da casa esboçaram visão semelhante), onde os Exus são vistos como crianças que devem aprender e, diferentemente das outras linhas, onde os médiuns aprendem com os Guias, nesta linha, entidade e cavalo trocam ensinamentos. Destaco ainda 
estas visões acima citadas, já que dentro do Reino de Luz acredita-se que todas as entidades estão debaixo da capa ${ }^{19}$ do Seu Caveira - Exu chefe da casa - e que este não permite que se faça nada que prejudique alguém. Sendo assim, porque os Exus necessitam de tantos cuidados? Porque eles precisam ser tratados de forma diferente? ${ }^{20}$

Essas dicotomias estão presentes nos depoimentos de diversos participantes do Reino de Luz e elas demonstram como, mesmo nós umbandistas, que lutamos para nossa religião não ser alvo de preconceitos, estamos imbuídos das mesmas ideias que servem para fundamentar as criticas relativas à Umbanda. Isto se mostra presente também quando vemos, em algumas entrevistas, alguns membros da corrente dizerem que gostariam de mudar os pontos de Quimbanda, ou que não cantam certos pontos de Quimbanda devido às letras destes.

Outra importante colocação de Lucas diz respeito ao Povo de Quimbanda "por eles serem mais próximos da gente. $E$ a gente acaba se.. acaba se unindo mais a eles, entendeu? Eu vejo como um povo bem legal de trabalhá", essa é uma visão corrente dentro da terreira e faz com que as festas de Quimbanda sempre sejam aguardadas com ansiedade, alguns médiuns adoram estas festas enquanto outros sentem-se desconfortáveis. Carmen pensa desta forma

Carmen - "[...]. 0 povo de Exu, que é um povo que eu tenho muita [...] e uma confiança hoje [...] mas não foi sempre assim, porque? Porque todo esse ritual que se faz pro povo de Quimbanda, eu.. me agride! Me agride. [...] alguns irmão da corrente ainda dizem que foi esse $0 . .$. um fator assim ó, principal de nós termos caído, do nosso grupo ta desintegrado, de nós não termos mais casa, que.. que foi essa mudança no ritual ${ }^{21}$ de Exu. [...] [mas] Não foi isso..."

Eu - "Porque assim, tem muitas pessoas que até.. de fora da religião, que ligam a figura do Exu com a figura do diabo, Exu e diabo.."

Carmen - "Eu não ligo... eu não ligaria ao diabo, eu ligo a figura do Exu as nossas coisas terrenas, as nossas fragilidades, a todos os, entre aspas, pecados, as coisas da carne. [...] e também ao ritual do... da homenagem aos Exus. Por exemplo aquela coisa assim ó, dos vestidos decotados, das.. atitudes sensuais, da bebida, daquela... daquela festa assim.. eu não quero sê exagerada, mas daquelas $\operatorname{orgias}^{22}$.Eu acho que não tem nada a vê com religião aquilo ali. Aí vão dizê assim: "Ah, mas tu não gosta de te enfeitá e de ir num baile?" Gostava, na época que ia com meu marido adorava e sinto fala até hoje. Gosto de me vestir, Gosto duma roupa decotada, Gosto dum copo cheio de cerveja, mas na festa, não na hora que eu to me propondo a fazê um ritual religioso pra evolução espiritual."

Eu - "E tu acha que são esses rituais, por exemplo, que levam as pessoas de fora da Umbanda a fazêesse tipo de ligação?"

Carmen - "Com certeza." (Em entrevista a autora, 01/05/08)

Outros membros da corrente do Reino de Luz também possuem este tipo de posicionamento, como o de Carmen. 0 ritual da Quimbanda os incomoda, pois "não tem nada a ver com religião", em contraposição com o ritual de Umbanda, que seria visto como religião. Acredito que estas visões estão ligadas as histórias de cada participante. Carmen, como se pode ver nas entrevistas em anexo, teve uma criação católica e, devido a experiências as quais esta religião não explicava, passou a frequentar o Kardecismo e depois a Umbanda. Quando mudamos de religião, não nos descolamos de nossa bagagem anterior e, de certa forma, de nossas crenças. Deste modo, nosso modo de ver esta nova religião está impregnado pelas experiências vividas na religião anterior.

\section{4 - Voltando ao campo sonoro}

Poucos são os umbandistas do Reino de Luz que "nasceram" na Umbanda, deste modo essas dicotomias entre as práticas umbandistas e as vivências em outras religiões se cruzam e fazem com que as interpretações acerca das práticas do Reino de Luz sejam vistas de formas diferentes entre os participantes. Neste contexto, alguns participantes não gostam dos pontos de Quimbanda, porque eles remetem a coisas que não estariam dentro do que estas pessoas acham que seriam práticas religiosas como as festas, por exemplo, (ver depoimento da Carmen, acima citado, onde esta explica a situação). Podemos ver, na foto abaixo, uma cena comum nestas Festas (Ex.3).

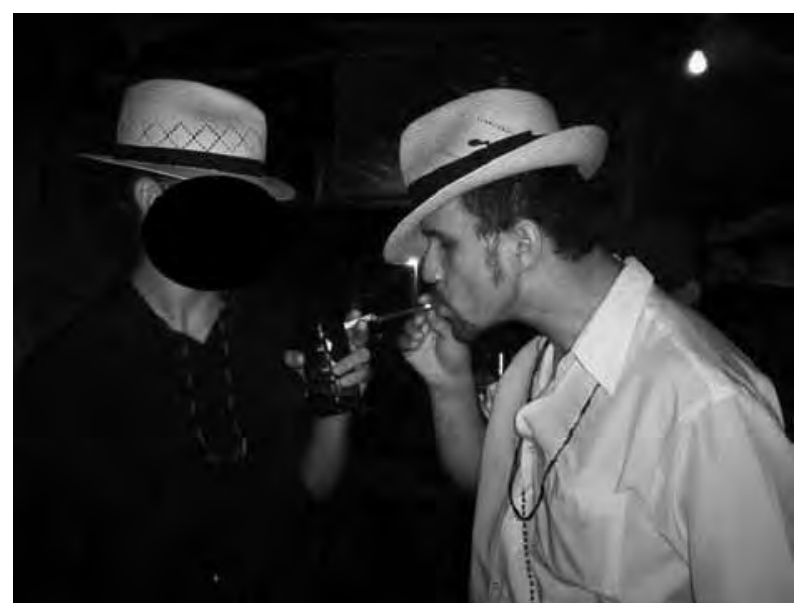

Ex.3 - Foto de dois Zé Pelintra em uma festa de Quimbanda.

Roberto da Matta em "Carnavais, malandros e heróis" se utiliza de duas categorias em sua análise, a rua e a casa. 0 autor argumenta, "[...] realmente, a oposição entre rua e casa é básica, podendo servir como instrumento poderoso na análise do mundo social brasileiro, sobretudo quando se deseja estudar sua ritualização" DA MATTA (1981,p. 70). A casa seria vista como um lugar de harmonia, calma, remetendo "[...] a um universo controlado, onde as coisas estão nos seus devidos lugares" DA MATTA (1981, p. 70). A rua, ao contrário, seria "[...] basicamente o mundo, com seus imprevistos, acidentes e paixões...",

[...] na rua é preciso estar atento para não violar hierarquias nãosabidas ou não-percebidas. E ainda para escapar do cerco daqueles que nos querem iludir e submeter, pois a regra básica do universo da rua é o engano, a decepção e a malandragem, essa arte brasileira de usar o ambíguo como instrumento de vida...DA MATTA (1981, p. 70)

A coincidência é que as entidades de Quimbanda são chamadas também de Povo da Rua e uma das linhas desse 
povo é a de Zé Pelintra, os malandros ${ }^{23}$ descritos por Da Matta. Inclusive esta descrição do autor de que é preciso estar atento para não ser enganado na rua, corresponde à colocação, já citada, que alguns participantes da casa fazem do relacionamento entre médiuns e as entidades da Quimbanda, a respeito do cuidado que é necessário ter com tais espíritos. Exatamente por essa ligação com a rua, segundo a categoria de Da Matta e também a categoria prevista dentro do universo do Reino de Luz, é que o Povo deQuimbanda é visto como próximo de nós. Segundo Vânia Zikán Cardoso, "o próprio nome dos espíritos [Povo da Rua] nos remete para fora dos espaços delimitados da performance do ritual em direção ao espaço mundano das ruas e do dia-a-dia" CARDOSO (2007, p. 322), como podemos observar nos exemplos abaixo (Ex.4 e Ex.5).

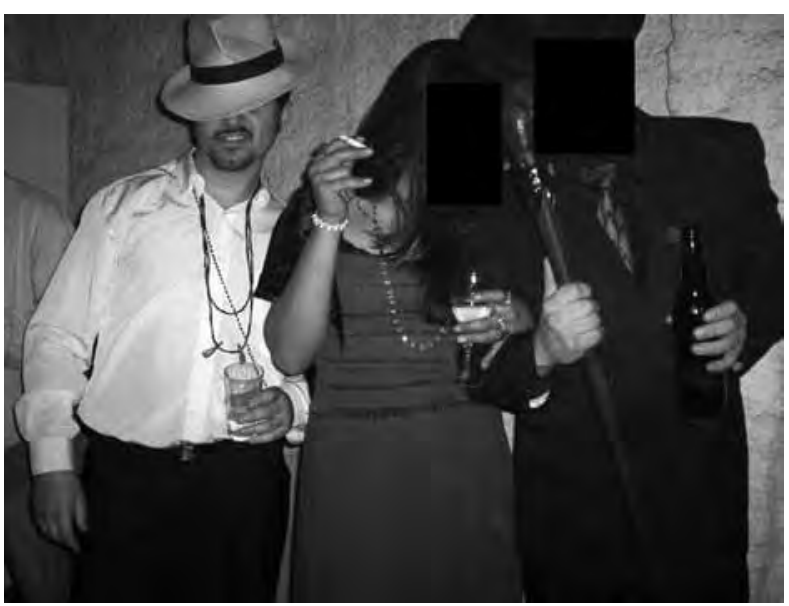

Ex.4 - Zé's Pelintra e Pomba-Gira Sete "Catatumba", foto retirada em uma festa de Quimbanda da casa.

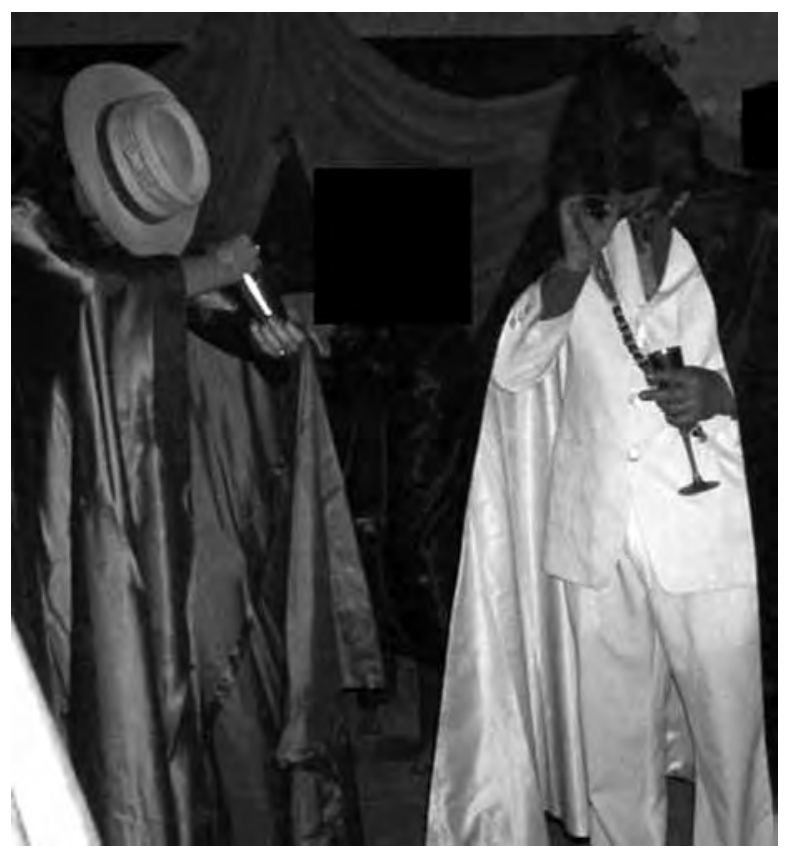

Ex.5 - Foto de uma cena da mesma festa de Quimbanda, Exu Tiriri e Exu Caveira.
Além de o universo visual dos rituais de Quimbanda nos remeterem à rua - como vimos nas fotos acima - o campo sonoro desta linha remete a este mesmo universo, alguns Exus e Pomba-Giras dão gargalhadas quando chegam à terra, o toque do atabaque é mais acelerado e cheio de variações, as luzes são apagadas e acesas luzes vermelhas, as festas ocorrem da meia-noite às quatro da manhã (como já dito). Os sons da Quimbanda são sons da rua. As Festas de Quimbanda - como o próprio nome já diz - lembram festas "comuns", isto é, não religiosas, com bebidas, risadas, música e conversas. Utilizando a metáfora "pontos de escuta"24 TRAVASSOS(2005, p. 94), quando muitas pessoas ouvem as Festas de Quimbanda, seus "pontos de escuta" as remetem para a rua e não para uma festa religiosa. A Quimbanda homenageia o Povo da Rua, o senso comum o reprova, alguns umbandistas reprovam as Festas de Quimbanda por "isso não ser religião", neste sentido, o que remete a rua é visto como não próprio para religião.

Gostaria de ressaltar que posicionamentos semelhantes aos de Carmen - citada acima - não se restringem somente às práticas rituais, mas se estendem também às práticas sonoras da linha de Quimbanda.

Eu - "Tem alguns pontos de Quimbanda que são proibidos no Reino de Luz, tu.. que explicação tu dá para isso? Por que que isso acontece? Como tu vê essa proibição?"

Lauren - "Porque ali tu ta fazendo religião, entende? Tem pontos que são assim.. tem muitos pontos mesmo aquele que fala que Pomba-Gira é... que Pomba-Gira é mulher.." Eu - "Do diabo?" Lauren - "É... é uma coisa assim, tipo, vamos supor, esse é um deles, entende? Eu... eu, por exemplo, não canto. Se eu ouvir esse ponto, eu, por exemplo, não canto porque, tipo, eu não acredito. Então.. e se tu.. por exemplo, vamos supor, aquela hora mesmo que tu me perguntou da questão de porque que as pessoas ligavam a imagem do Exu ao diabo. A pessoa.. aí, tu vai lá e faz toda uma explicação de como é que funciona e tal, ai a pessoa chega na terrera, "não, então vamo lá vê como é que é esse negócio", ai a pessoa chega numa Quimbanda e escuta um ponto desses: "ué mas eles tão cantando.... Porque na igreja tu canta o que é, tu canta o que tu exalta. Aí tu chega lá na Quimbanda e escuta um ponto desses, tu ta exaltando isso, então realmente, é uma religião do diabo! (risos)" (Em entrevista a autora, 28/04/08)

Lauren chama atenção para o fato de que quando cantamos uma canção ritual, estamos exaltando as entidades às quais os pontos se referem e que, quando cantamos um ponto como este disposta abaixo, estariamos exaltando isto (Ex.6).

Para esta entrevistada, além dos pontos proibidos ${ }^{25}$, outros não deveriam ser cantados. Além disto, podemos notar no relato de Lauren uma preocupação comum a outros umbandistas: se a religião não cultua o diabo e nem faz o "mal", e os adeptos a esta tentam sempre demonstrar isto, como cantaremos pontos que falam de diabo, sangue, etc.? Estaremos então demonstrando às pessoas que chegarem à casa, e não forem adeptas a esta, que cultuamos tais figuras e práticas, como exemplificou Lauren em seu depoimento citado acima. 


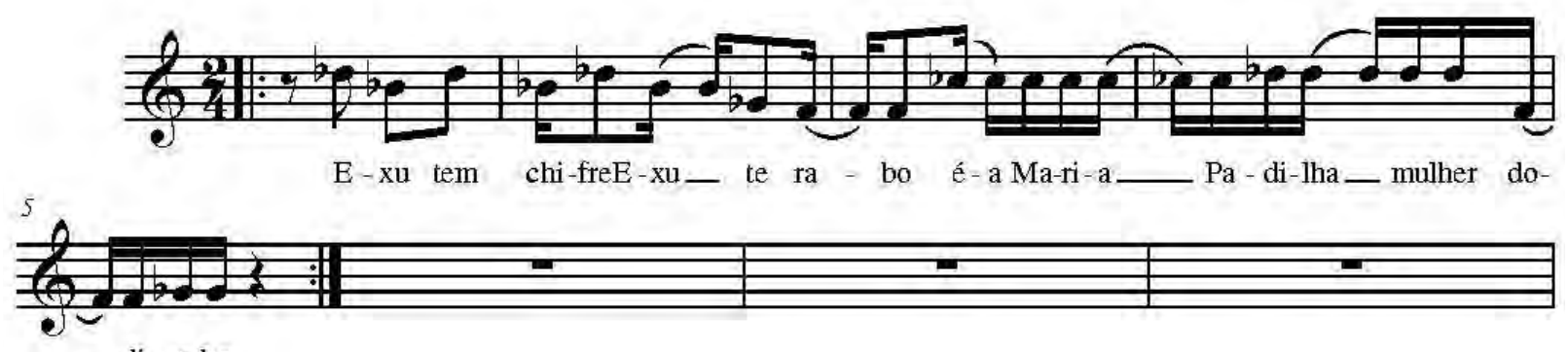

di - a-bo

Ex.6 - Ponto de Pomba-gira Maria Padilha, recolhido no Terreiro de Umbanda Reino de Luz.

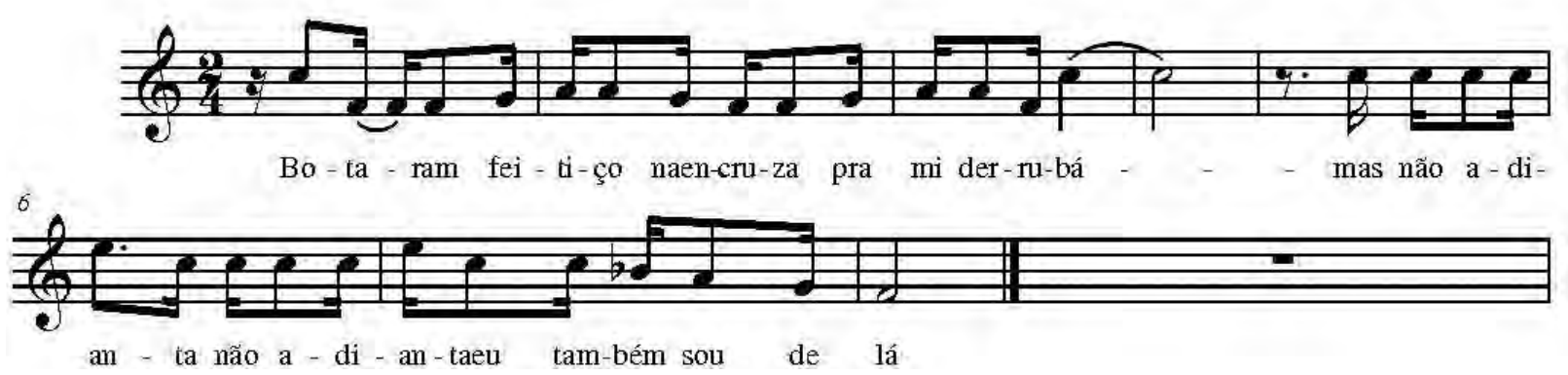

Ex.7 - Ponto de Exu da Encruzilhada cantado no Reino de Luz.

Carmen pensa de forma semelhante, diz que acha que "a música é fundamental, ela eleva o espírito da pessoa pra aquilo que ela ta vivendo naquele momento. Eaí é que entra a questão, os pontos na... na linha de Exu, não gosto dos pontos de Exu"(Em entrevista a autora, 01/05/08). Carmen ainda ressalta o porquê de não gostar de tais pontos "Não gosto. Não gosto, acho eles assim ó... aquelas coisas de.. cavera, de.. sete-palmos, de.. no lixo, do "te mato", do "é terrivel", eu acho que isso aí não em nada a vê com religião, não gosto". Além de Lauren e Carmen, Lom - Cacique da casa - possui visão parecida em relação aos pontos de Exu executados na terreira

Lom - "Eu sinto... a música.. de.. várias formas. Vejo como.. um poema, como.. uma homenagem, como uma oração. Todas as composições e todas as vibrações que são feitas pras mães, pros pais, pros Orixás maiores, assim como dos Pretos-Velhos, são... bálsamo pros meus ouvidos, embora eu tenha restrições aos pontos que são feito e cantados para os Exus.. porque eles ainda vem carregados da história do Exu comparado a figuras demoníacas, figuras da noite, figuras permissivas. Mas não é a batida, não é o som que m'incomoda, o que m'incomoda são as letras."

Eu - "Então, tu tás falando dos pontos que não podem ser tocados na Quimbanda do Reino de Luz?"

Lom - "Não. Inclusive os pontos que são tocados no Reino de Luz, se fosse.. se eu tivesse poder pra tanto, eu mudaria todos eles."

Eu - "Como... como, por exemplo?"

Lom - "Portão de ferro / Cadeado de madeira / É lá no cemitério
I Onde mora Exu Cavera". Exu Cavera é algo transcendental, ele é do universo, como é que ele mora no cemitério? Dai aos mortos seus mortos..o que é morto é morto. Cemitério é um campo santo para as pessoas que morreram não pra nós vivos. É um dos campos de atuação do Exu Cavera? Sim, mas não é só lá. O... outro ponto de Exu Cavera que diz... é... "Não brinque com Cavera / Ele não é brincadera / Quem... mexe com.. com ele / Vira defunto... Eu - "vira pó" Lom - "ou vira cavera". É, são coisas que... que conhecendo a grandeza desse espírito, sabe que não é assim, mas faz parte da história da nossa religião, que não é nem sincretismo, é uma maquiagem que foi feita, uma associação que foi feita, só que, tudo que é criado, embora seja criado em cima de uma mentira, com o passar do tempo se torna uma mentira verdadeira. Então essa associação, ela é natural hoje." (Em entrevista a autora, 27/04/08)

Mesmo que Lom não goste de alguns pontos, estes ainda fazem parte do repertório cantado na casa, mas é importante ressaltar que ele, como Cacique da terreira, possui o poder de proibir a execução de alguns pontos, caso assim o desejasse. Devido ao fato de, assim como Lom, alguns participantes não gostarem das letras dos pontos de Quimbanda é que estou dando tanta atenção a estas, já que são o principal motivo de restrições por parte de alguns umbandistas.

Estes participantes citados acima não gostam dos pontos de Quimbanda devido às suas letras, por acreditarem que estas não correspondem à realidade dos cultos da casa. Como a letra do ponto abaixo (Ex.7). 
0 ponto acima citado fala de colocar feitiço na encruza para derrubar alguém e este tipo de prática não é permitida no Reino de Luz. Por este motivo alguns participantes da casa não gostam das letras dos pontos de Quimbanda, pois se alguém ouvir este ponto poderá achar que esta (fazer feitiço) é uma prática da terreira em questão e isto não corresponde à realidade.

\section{5 - Sobre a visão de morte na Umbanda, mudanças rituais e suas relações com 0 campo sonoro}

Gostaria de destacar também duas coisas, a primeira é que apesar de Lom, em seu relato acima citado, dizer que o cemitério é um lugar santo para os mortos não para os vivos, alguns umbandistas do Reino de Luz consideram este local santo. A segunda é a visão que os seguidores desta religião têm da morte. Débora explica estas duas questões por mim destacadas.

\footnotetext{
Eu - "Tu achas que esse tipo de ligação é.. a imagem, que.. as pessoas de fora da religião fazem do Exu ao diabo e até dessas pessoas da religião que fazem questão de fazê essa ligação, causam algum tipo de efeito na gente que cultua a Quimbanda? Na gente como médium?"
}

Débora - "É, na realidade dá conta disso não é uma coisa muito fácil. [...] Nós somos ligados a pessoas que fazem matanças de animais e nós não fazemos isso. Nós somos ligados as pessoas que vagam pelos cemitérios, "fazendo o que dentro dos cemitério?" "0 que essa gente faz dentro dos cemitérios?" Só que... as pessoas não entendem que o umbandista, ele lida com a morte da mesma forma como ele lida com a vida. Como nós somos re-encarnacionistas, como nós somos espiritualistas, nós acreditamos no espírito, falá da morte e entrá em ambientes em que a morte circunda é muito natural pra nós. [...] "Ah, as pessoas cantam pontos de cemitério, fazem rezas de cemitério". Tem pessoas que vivem na... pessoas que viviam no campo compunham canções de pastoreio, tem pessoas que vivem em meios urbanos e fazem músicas que refletem o meio urbano. Nós fazemos religião, nós repetimos a nossa espiritualidade, a nossa espiritualidade, ela é embasada na vida de na morte. Nós cultuamos.. espiritos que lidam com a saúde, com a vida e com a morte[...] Então pra nós, ir fazê um trabalho uma vez por ano, duas vezes por ano de gira [...] nós pisamos em cemitério sim porque é um lugar sagrado. Importantíssimo pra nós. Como é o nosso Congá. Nós temos um Congá dentro do terreiro, nós homenageamos lemanjá na água, nós homenageamos Oxóssi na mata, nós homenageamos Omulú dentro do cemitério. [...]E isso não quédizê que isso esteja fazendo mal pra alguém. [...] tu vê como nós, mesmo escondidos interferimos na vida das pessoas, mesmo resguardando nossos mistérios, nós estamos SIM influindo na vida das pessoas, porque as pessoas às vezes vêem as.. os médiuns entrarem de vermelho e preto, cemitério a dentro, elas se sentem apavoradas, agredidas. Uma vez nós fomos fazê (riso) uma entrega na frente do, do portão, nós não entramos, no portão do cemitério (riso meu), tu estava junto? Te lembra? Eu - "Tava". Débora - "Uma igreja evangélica na frente, veio a igreja inteira, inteira.. e a gente viu o desespero no rosto daquela gente, porque Pra Eles nós estávamos fazendo mal pra alguém. Eu - "E os cartazes colados na porta do cemitério, convidando para í pra igreja?" Débora - "E os cartazes! Convidando pra ir pra Igreja! E na realidade, nós estávamos fazendo um ritual de agradecimento! Então vê que NUNCA, eu posso dizê Com Certeza, não é uma vez, nem outra, NUNCA, quando um leigo vê um umbandista, um batuqueiro, ou... um crente da Nação, ou.. quando vêem uma entrega, um presente ou uma oferenda, eles já acham que é um despacho, NUNCA a primeira ideia é de que pode ser um presente pro "bem" pra alguém, a ideia é sempre que "aquela gente que veste preto e vermelho, preto e branco, aquela gente tá indo fazê mal pra alguém", "ora, eles tão na porta do cemitério!" E nós trabalhamos na porta dos hospitais também, não só na frente da porta do cemitério. Quantas oferendas um, quantas coisas um filho de Nação, que ele tem que percorrer vários lugares, ele passa no cemitério, ele passa no hospital, ele passa no banco, ele passa na praça, são todos ambientes de culto, mas nenhum desses ambientes são tão ameaçadores quanto o cemitério. [pausa] Porque o cemitério, como é ligado à morte, e as pessoas vêem a morte como uma coisa má, que separa elas dos seus bens, "tás fazendo mal pra alguém", pois se tu vais fazer uma coisa boa, não vais fazê na porta do cemitério, né? A ideia é essa! (risos)" (Em entrevista a autora, 25/07/08)

Em seu relato, a entrevistada fala de questões muito importantes para a religião. Débora chama atenção para o modo como a morte faz parte da cosmovisão umbandista e, exatamente por este motivo, o cemitério é um lugar santo, além de relatar um conflito entre crenças através de uma das tentativas utilizadas por fiéis de outra religião de converter os umbandistas, "salvando-os do demônio", como dizia nos cartazes.

Por serem, como explica à entrevistada, os adeptos da Umbanda reencarnacionistas, estes enxergam a morte como mais uma etapa do passar do espírito na terra, isto é, o espírito encarna, nasce, vive e passa pelas experiências necessárias para seu aprendizado e morre/desencarna. É um processo cíclico. E, sendo assim, faz parte das crenças e práticas desta religião. A linha de Quimbanda, e principalmente a linha de Exu, é a mais ligada à morte.

$\mathrm{Na}$ Umbanda, assim como a morte é vista como parte da vida e da religião, os locais comumente relacionados à morte são considerados locais de culto e sagrados, como destaca Débora. Deste modo, fazer rituais nesses locais é parte dos ofícios religiosos e não estão relacionados ao "mal". Diego explica

Diego M. - "Eu acho que esse... tipo [de modernização da religião], tu não vê um.. jovens querendo trabalhá com Caboclo, com PretoVelho, que são a alma da Umbanda, entende? Tu vê, hoje, jovem que quéentrá e quétrabalhá com Tranca-Rua, porque ele [o jovem] qué... porque ele julga, na cabeça dele, que ele qué sê no dono da rua. Tu vê jovem querendo trabalhá com o Cavera porque é o Exu da morte. Quando eu digo Exu da morte, que pra quem conhece sabe que é ele que faz o desligamento da pessoa e encaminha essa pessoa pra Luz, então... ou querem trabalhá com Omulú por sê dono do cemitério, entende? [...]" (Em entrevista a autora, 01/05/08 - grifos meus)

Exu Caveira, como apontado por Diego, é o Exu responsável por fazer o desligamento do espírito de seu corpo material, sendo considerado o "Exu da morte". 0 que considero difícil de entender para quem não é umbandista é que o fato de Exu Caveira ser o "Exu da morte" não quer dizer que ele "mate" as pessoas e sim que conduz elas na morte. "Portão de ferro, cadeado de madeira (2x) / Lá no cemitério, onde mora Exu Caveira (2x) ${ }^{26 "} 0$ cemitério, neste ponto, é a representação da morte, logo, os Exus são do cemitério e os umbandistas cantam isso. Cantam a morte. Mas não porque venerem a morte e sim porque acreditam que esta faz parte da vida.

Débora, em seu depoimento acima citado, também destaca como a maioria das pessoas que não faz parte da Umbanda, ligam ao "mal" tudo que está relacionado ao cemitério 
e a morte. Deste modo, para estas pessoas, a Linha de Quimbanda é vista como o "mal" em si. Segundo Bosi

\begin{abstract}
A civilização burguesa expulsou de si a morte; não se visitam moribundos, a pessoa que vai morrer é apartada, os defuntos jà não são contemplados. 0 leito de morte se transformava em um trono de onde o moribundo ditava seus últimos desejos ante os familiares e vizinhos que entravam pelas portas escancaradas para assistir ao ato solene... A morte vem sendo progressivamente expulsa da percepção dos vivos. BOSI $(1983$, p. 46-7)
\end{abstract}

Enquanto a "civilização burguesa" expulsa a morte de suas práticas, os umbandistas a celebram através de seus cantos e práticas rituais da linha de Quimbanda. Como neste ponto de Exu Tranca Ruas das Almas (Ex.8).
Outra questão importante a se destacar, é que para muitas pessoas a morte é vista como algo ruim, sempre relacionada à tristeza, como a separação imposta entre as pessoas que estas têm afeto (como fala Débora em seu depoimento acima citado) ${ }^{27}$. Acredito que por isso muitas pessoas neguem tudo o que diz respeito a morte, tirando-a de suas vidas. Para os umbandistas não é que a morte não seja triste, eles também sofrem a falta de seus entes queridos, mas esta é vista como mais um passar (o que temos que passar enquanto estamos encarnados), como algo inerente da condição de estarmos vivos.

Carlo Ginzburg em seu artigo intitulado "Matar um Mandarim Chinês - as implicações morais da distância",
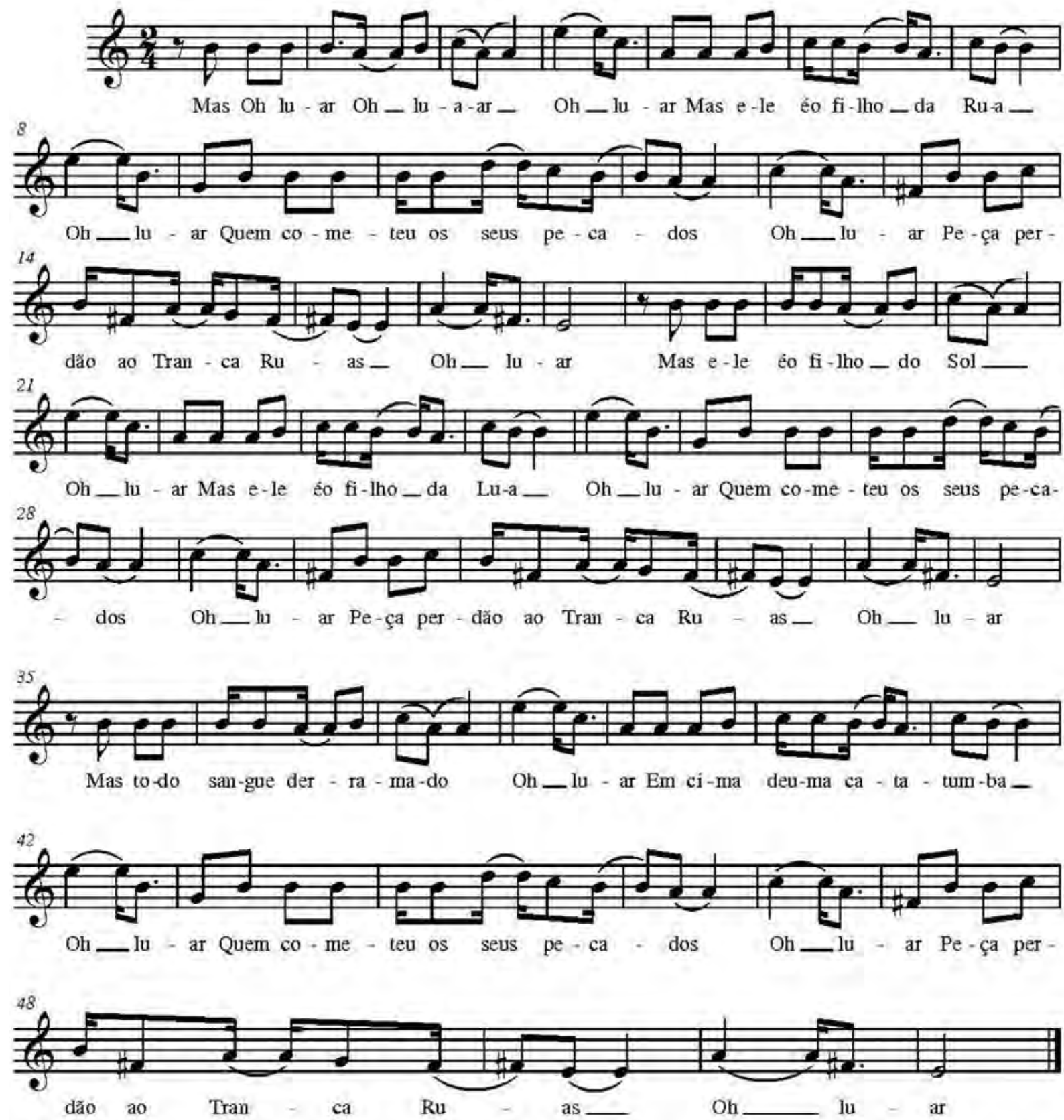

Ex. 8 - Ponto de Exu Tranca Ruas das Almas. 
presente em sua obra "Olhos de Madeira - nove reflexões sobre a distância", reflete sobre distância e proximidade, lembrando-nos que tudo que se encontra mais perto de nós, nos atinge mais. Sendo assim, a proximidade com a morte nos traz o incômodo de refletirmos sobre ela e, talvez por isto a sociedade burguesa, da qual fala Bosi, exclua-a de suas práticas.

Além disso, a morte não é só cantada, ela está presente nas representações visuais e, até mesmo, nos nomes das entidades dessa linha. Muitas estátuas de Exu são esqueletos ou levam na mão uma caveira, ou estão ao lado de um túmulo e geralmente remetem ao cemitério e representam a morte. Podemos ver isto nas fotos Congás montados especialmente para as festas (Ex.9, Ex. 10 e Ex.11).

Alguns nomes de Exu e Pomba-Gira: Exu Caveira, Exu "Sete-Catatumbas"28, Exu do Cemitério, Exu Porteira, Pomba-Gira Rainha das Sete Encruzilhadas, PombaGira "Sete Catatumbas", Pomba-Gira Maria Padilha das Almas, Pomba-Gira Rosa Caveira, etc.

A morte também estava presente, inicialmente, nas práticas de assentamento da casa. Uma das práticas rituais da Quimbanda é o assentamento de Exus, esta serve para fortificar estas entidades para que tenham mais força na hora de trabalhar e defender a casa e seus cavalos, além de outros preceitos religiosos. Acredita-se que é através dos assentamentos que os Exus aumentam suas forças, por este motivo eles são realizados de tempos em tempos.

No ano de 2005 foi realizado o último assentamento do Reino de Luz antes da casa fechar, mas desta vez houve uma mudança no ritual, o sangue dos animais foi substituído por sumo de frutas. A explicação dada pelo Cacique era de que o Exu chefe da casa não achava que fosse necessário continuar com a matança de animais, que os Exus da casa deveriam se desenvolver e que a força advinda do sangue poderia vir do sumo das frutas, isto é, se substituiria o sangue dos animais pelo "sangue das frutas".

Esta medida provocou muitos conflitos dentro da casa e há quem pense que esta mudança é um dos motivos pela casa estar fechada hoje já que os Exus são responsáveis pela parte material e - segundo os adeptos desta teoria - havendo mudança em seus rituais, estas entidades não estariam satisfeitas e por isso não estariam cumprindo com suas responsabilidades.

Para os adeptos da Umbanda, a vida espiritual influencia na vida material, deste modo as mudanças rituais acabam refletindo nas vidas dos médiuns da casa. Alguns destes que possuem Exus assentos pela feitura (ritual) antiga, dizem que o modo de incorporação da entidade em questão mudou depois que eles realizaram o assentamento com matança, sendo a incorporação mais densa. Quando perguntei a Diego P. sobre o toque

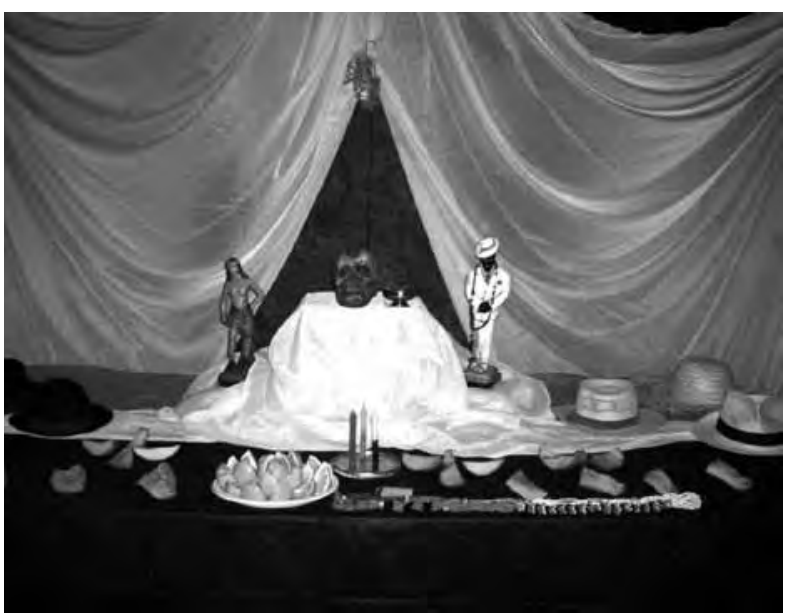

Ex.9 - Congá da Festa em homenagem ao Exu Caveira, Pomba-gira Maria Padilha das Almas e Zé Pelintra do morro.

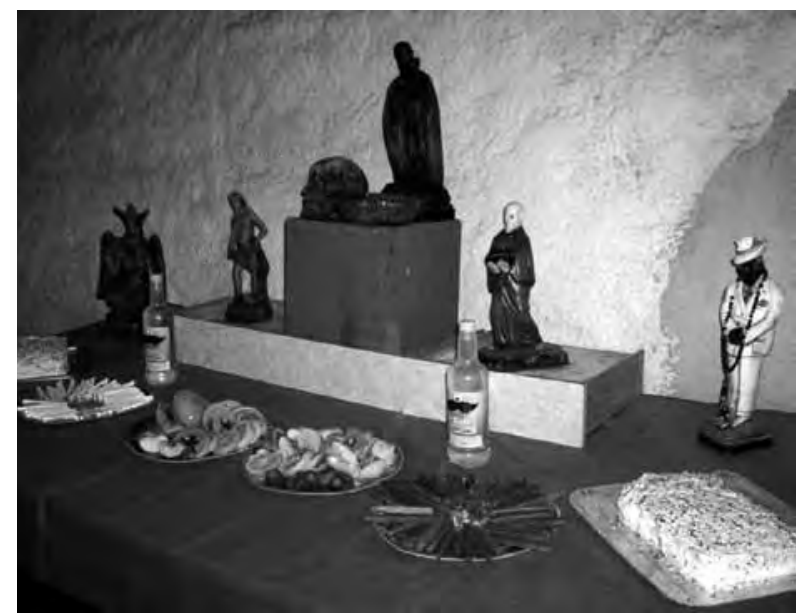

Ex.10 - Congá da Festa em homenagem ao Exu Destranca Ruas.

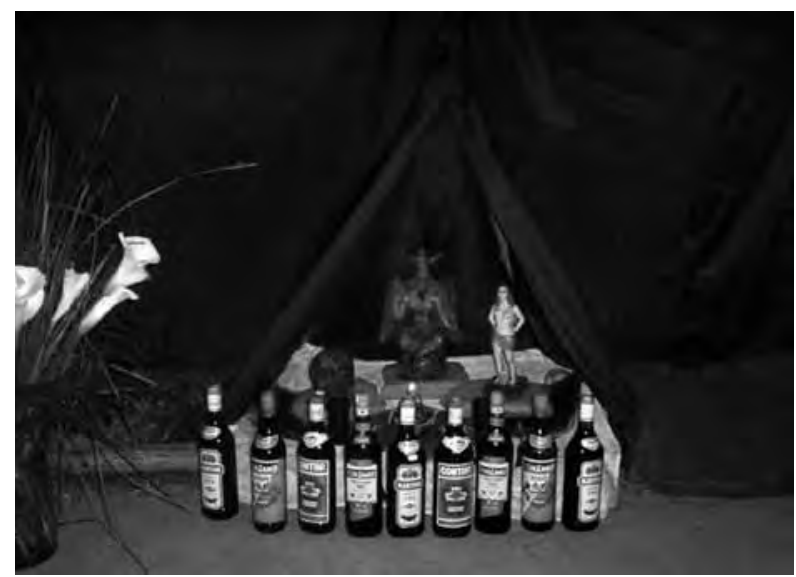

Ex.11 - Congá da Festa em homenagem ao Exu Maioral. 
de Umbanda e o de Quimbanda ele acabou falando de como estes mudaram com o passar do tempo e conduziu a entrevista para a questão das mudanças rituais.

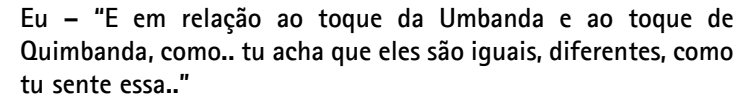
Quimbanda, como.. tu acha que eles são iguais, diferentes, como tu sente essa.."

Diego Peres - "É.. na verdade, quando eu entrei eles eram bem diferentes um do outro, mas hoje, por certas mudanças que ocorreram na casa, já.. eles já são muito parecidos."

\section{Eu - "E porque que tu acha que essa mudança aconteceu?"}

Diego Peres - "Eu acho que essa mudança aconteceu, [...] e acho que isso aí não é tanto pelo lado da música, eu acho que é mais é por parte de rituais que a Umbanda tem e que não deveriam sê tirados. $\mathrm{Ou}$, que se fossem tirados, fossem tirados desde o primeiro dia, porque aí médium não se acostumariam com certas coisas, porque mal ou bem certos rituais influenciam naquela energia que sai..."

Eu - "E quais.. alguns rituais foram tirados?"

Diego Peres - "Foram."

Eu - "Quais, assim..."

Diego Peres - "[...] vô te dá o exemplo [...] o que eu mais sinto falta é... é o sangue, mesmo eu não tendo [...] tu nota que na volta daquelas pessoas que já tinham aquele ritual.. [...] porque.. mal ou bem a Umbanda tem tudo que a Quimbanda tem, porém a Quimbanda tinha algo a mais, ela tinha uma força mais densa, mais pesada, por causa de certos rituais, que hoje não existe mais.." (Em entrevista a autora, 28/04/08)

Outro ponto importante de ser ressaltado é que, sendo a Umbanda - do modo como é praticada no Reino de Luz uma religião muito ritualística, as mudanças rituais acabam abalando a fé dos médiuns, ainda mais em se tratando desta mudança. Sobre as mudanças, Vanessa coloca o seguinte:

\begin{abstract}
"Eu não sei por que assim, pra mim não. Eu sou a favor de quem faça, eu acho que é uma lei da religião, eu acho que deve ser cumprida, não tem porque purificar nem nada, porque eu acho que a gente vai acabá se perdendo nisso [...] eu acho que assim, a minha fé nunca foi depositada em coisas que eu dei a entidades, em oferendas, em bebidas e coisas e tal. Mas tem fé de pessoas, por exemplo "x", depositou a fé dela numa... oferenda, ou naquele gesto ali de dá bebida, de servir todo dia o seu Exu, ou de dá o sangue pra ele. Então eu acho que isso acaba abalando e afetando um pouco cada um." (Em entrevista a autora, 01/05/08)
\end{abstract}

Pessoalmente eu penso como a Vanessa, e, confesso que, na época, me senti muito aliviada pela mudança ritual. Eu realmente não era capaz de entender o que de "tão importante" meus irmãos de corrente estavam perdendo com aquilo. Para mim era um alívio fazer parte de uma terreira que não mais praticava estes ritos tão ultrapassados e desnecessários ${ }^{29}$. Hoje, provavelmente, eu não veria as coisas deste modo.

Alguns dos médiuns mais antigos da casa, quando foi feito o primeiro assentamento, não queriam participar da matança, mas como esta era parte dos ritos religiosos, estes médiuns aceitaram e acabaram incorporando este como seu modo de fazer religião, eles aprenderam assim, confiaram no Cacique e em suas entidades que disseram que isto era necessário. Estas passaram a ser as suas verdades. Um dia isto não era mais necessário, o sangue

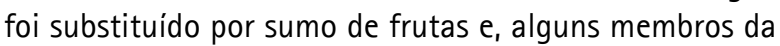
casa, questionaram muito esta substituição. Este processo

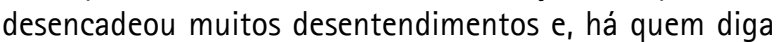
que algumas pessoas se "perderam no caminho", o que resultou na saída de alguns membros da casa.

O Povo de Quimbanda foi utilizado, no início da religião, como modo de proteção desta - como cita Lom em seu depoimento e Renato Ortiz em "A morte branca do feiticeiro negro". Assim a associação do Exu ao diabo foi utilizada como um modo de defesa através do medo que as pessoas tinham do demônio. Débora destaca - em trecho de entrevista já citado - que

\footnotetext{
"Nós somos ligados a pessoas que fazem matanças de animais e nós não fazemos isso... Então pra nós, ir fazê um trabalho uma vez por ano, duas vezes por ano de gira, não é de matá bicho, de fazê Baladê. Nós não fazemos isso. Existem casas que fazem? Existem, cultura deles. Eu respeito a cultura de cada um e o nível intelectual dos médiuns que ainda precisam disso." (Em entrevista a autora, 25/07/08)
}

0 trecho de entrevista citado acima ressalta um dos argumentos utilizados para a mudança do ritual de matança, que os médiuns do Reino de Luz não precisavam mais deste tipo de ritual. Interessante ressaltar que Débora foi uma das pessoas que brigou para que o ritual não fosse modificado, pois havia aprendido a religião desta forma, mas acabou aceitando a mudança e hoje, assim como outros participantes da casa, utilizam isto como modo de diferenciação de outros umbandistas. 0 interessante desta religião, é que, por não ter nenhuma codificação de práticas rituais, cada casa possui práticas independentes, mas, aos olhos dos não adeptos, todas possivelmente parecem iguais.

\section{6 - Fechando os trabalhos - conclusões}

Creio que, muitas vezes, a linha de Quimbanda é, e foi, utilizada para causar medo nas pessoas. Assim, por mais que os participantes do Reino de Luz afirmem que não praticam estes tipos de rituais, para quem "vê de fora" isto não é assim, ainda mais quando estes chegarem à terreira e escutarem um ponto como os abaixo. (Ex.12, Ex.13 e Ex.14)

\section{Como disse Lauren (em trecho já citado)}

\begin{abstract}
"... aí, tu vai lá e faz toda uma explicação de como é que funciona e tal, aí a pessoa chega na terrera, "não, então vamo lá vê como é que é esse negócio", ai a pessoa chega numa Quimbanda e escuta um ponto desses: "ué mas eles tão cantando...". Porque na igreja tu canta o que é, tu canta o que tu exalta. Ai tu chega lá na Quimbanda e escuta um ponto desses, tu ta exaltando isso, então realmente, é uma religião do diabo!" (Em entrevista a autora, 28/04/08)
\end{abstract}

Olhando a questão por todos esses prismas, acredito que as mudanças rituais e as citadas recusas de cantar certos pontos de Quimbanda ou de não gostar deles, podem ser interpretadas como uma tentativa de adaptação das práticas da terreira para uma melhor aceitação por parte dos não-adeptos à religião e também pelos 


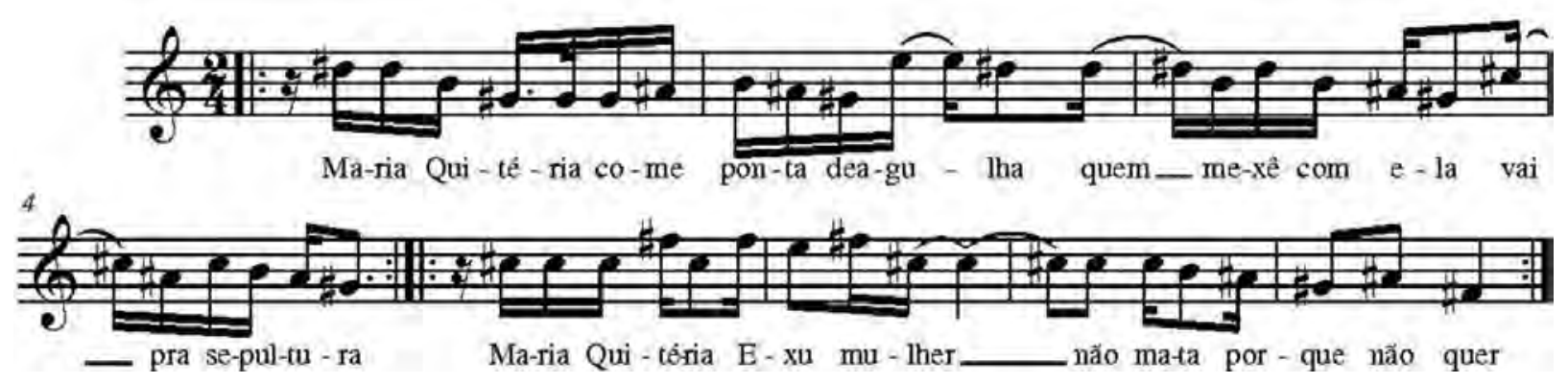

Ex.12 - Ponto de Pomba-gira Maria Quitéria recolhido no Terreiro de Umbanda Reino de Luz.

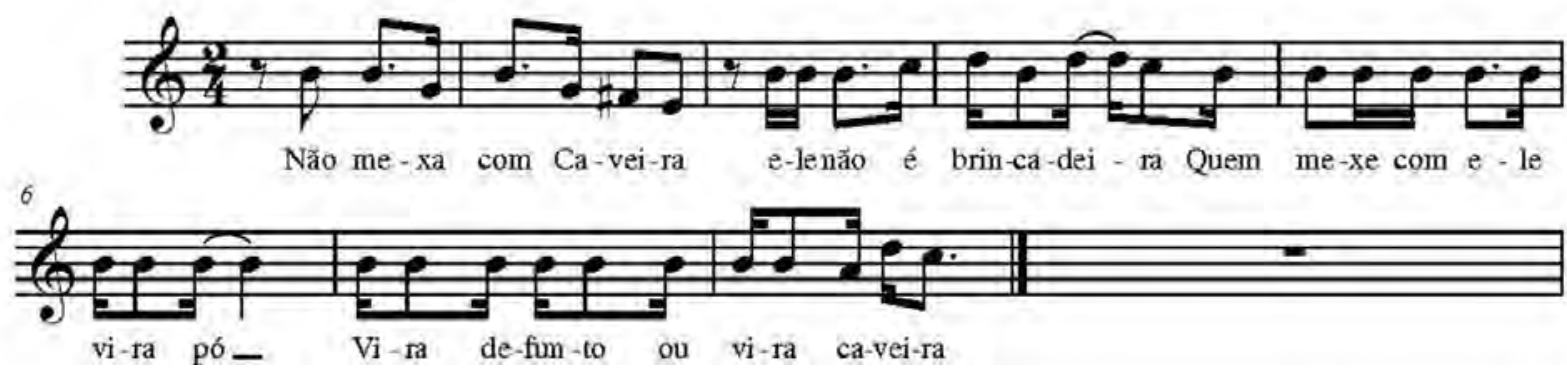

Ex.13 - Ponto de Exu Caveira cantando na casa em questão.

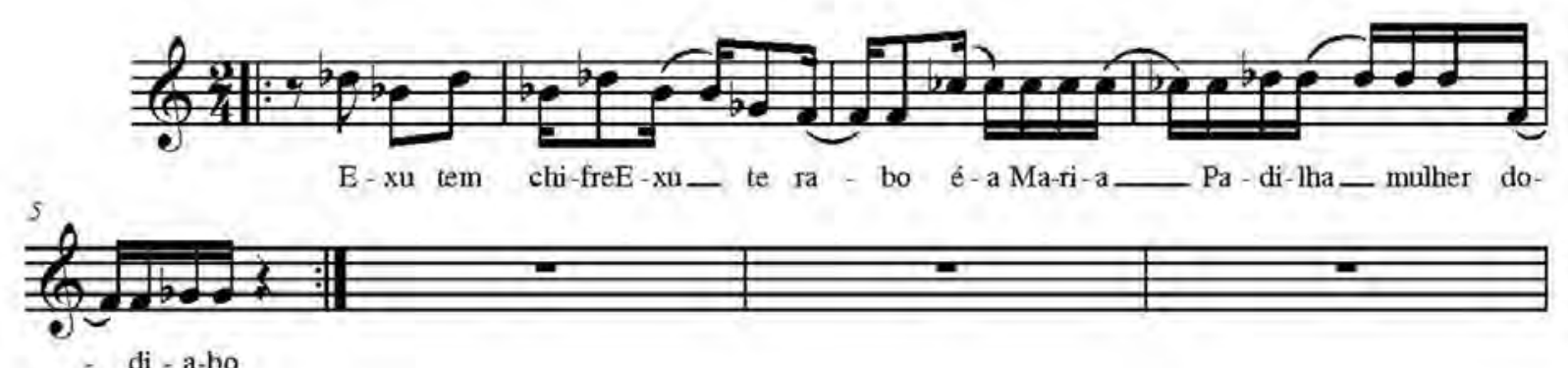

Ex.14 - Ponto de Pomba-Gira Maria Padilha.

próprios adeptos que não concordam que este tipo de imagem esteja ligada à religião que praticam. Está tudo interligado, a música feita na casa acaba por refletir uma imagem desta e uma das principais preocupações dos membros da terreira é tentar quebrar o estigma que sofrem por serem umbandistas. Ao cantarem os pontos de Quimbanda, de certa forma estão ajudando a perpetuar este estigma, pois estão passando a imagem de que praticam o "mal", ou "não mata $[\mathrm{m}]$ porque não qué [querem]" ou cultuam ao diabo, já que cantam "É Maria Padilha mulher do diabo".

Desta forma os umbandistas do Reino de Luz ficam numa encruzilhada entre as práticas e pontos cantados da tradição religiosa e suas tentativas de legitimação destas. Como se as duas coisas fossem contraditórias, pois estariam tentando uma legitimação através de diferenciação entre as práticas dos outros umbandistas e ao mesmo tempo cantando pontos que são contrários a esta diferenciação. Eles não fazem matanças, mas cantam estas. Eles não fazem trabalhos para o "mal", mas cantam estes, e assim por diante.

Diante dessa pesquisa e pensando em todos os fatores que se apresentaram neste trabalho, surgem muitos questionamentos: que preço os umbandistas estão dispostos a pagarem para mais bem aceitos? É isto mesmo que querem? Adaptar os rituais e a música, para serem mais bem aceitos? Desta forma não estariam negociando as suas identidades e crenças? Esta é, realmente, uma situação difícil. Como umbandista também gostaria que houvesse menos preconceitos sobre a nossa religião. E infelizmente, após analisar todos os fatores acima, entendo todos os posicionamentos e não me sinto capaz de julgá-los e dizer quais estão certos e quais são errados. Obviamente as pessoas querem viver em paz e seguir suas crenças religiosas sem ter que sofrer preconceitos ou ter que ficar explicando, toda vez que alguém descobre que são umbandistas, que não creem no diabo, que não fazem trabalhos para o mal e todas as situações que podemos ver descritas nas entrevistas. 


\section{Referências}

ALVARENGA, Lenny Francis Campos de. As ressignificação de Exu dentro da Umbanda. Dissertação de Mestrado apresentada ao Mestrado em Ciências da Religião da Universidade Católica de Goiás. Goiânia, 2006.

BOSI, Ecléa. Memória e Sociedade - Lembranças de Velhos. T. A. Queiroz Editor. São Paulo: 1983.

CARDOSO, Vânia Zikán. Narrar o mundo: estórias do "povo da rua" e a narração do imprevisível. MANA 13(2): 317-345, 2007. Disponivel em: http://www.scielo.br/pdf/mana/v13n2/02.pdf. Acessado em: 26 mar. 2009.

DA MATTA, Roberto. Carnaval, Malandros e Heróis. Zahar Editores. Rio de Janeiro: 1981.

DA SILVA, Vagner Gonçalves. 0 antropólogo e sua magia: Trabalho de Campo e Texto Etnográfico nas pesquisas antropológicas sobre religiões afro-brasileiras. São Paulo: EDUSP, 2006.

DA SILVA, Vagner Gonçalves. (org.). Intolerância Religiosa - Impactos do neopentecostalismo no campo religioso afrobrasileiro. Edusp. São Paulo: 2007

GINZBURG, Carlo. Olhos de Madeira - nove reflexões sobre a distância. Trad. Eduardo Brandão. Companhia das Letras. São Paulo: 2001.

GINZBURG, Carlo. 0 Queijo e os Vermes. Trad. Maria Betânia Amoroso. Companhia de Bolso. São Paulo: 2006.

MARIANO, Ricardo. Pentecostais em ação - a demonização dos cultos afro-brasileiros. In: SILVA, Vagner Gonçalves da.Intolerância Religiosa - Impactos do neopentecostalismo no campo religioso afro-brasileiro. Edusp. São Paulo: 2007.

MASSART, Guy. Viajantes Profissionais e Estrangeiros Cabo-verdianos no Rio de Janeiro: experiências do "outro". In: MAGGIE, Y.; REZENDE, C. (Org.). Raça como retórica - a construção da diferença. Civilização Brasileira. Rio de Janeiro: 2002.

ORTIZ, Renato. A Morte Branca do Feiticeiro Negro: Umbanda e Sociedade Brasileira. Editora Brasiliense. São Paulo: 1999.

PRANDI, Reginaldo. 0 Brasil com axé: candomblé e umbanda no mercado religioso. Estudos Avançados 18 (52), 2004. Disponivel em: http://www.scielo.br/pdf/ea/v18n52/a15v1852.pdf. Acessado em: 26 mar. 2009.

PRANDI, Reginaldo. Pombagira e as faces inconfessas do Brasil. In: Herdeiras do Axé. Hucitec. Capítulo IV, pág. $139-164$. São Paulo: 1996.

SEGATO, Rita. Racismo, discriminación y acciones afirmativas: herramientas conceptuales. In Educar en ciudadanía intercultural. Lima: Fondo Editorial de la Pontificia Universidad Católica del Perú: 2007.

TRAVASSOS, Elizabeth. Pontos de escuta da música popular no Brasil. In: ULHÔA, Martha; OCHOA, Ana Maria. Música Popular na América Latina - pontos de escuta. UFRGS Editora. Porto Alegre: 2005.

\section{Notas}

1 Utilizo a palavra terreira no feminino e não terreiro, pois é assim que os membros do Reino de Luz se referem ao local onde são efetuados os cultos. Optei pela utilização dos termos nativos.

20 termo corrente é utilizado para designar a totalidade dos membros da terreira, é uma metáfora onde cada participante é um elo desta corrente, de igual importância, e a união de todos estes elos forma a corrente da casa.

30 termo casa é utilizado pelos umbandistas como sinônimo de terreira.

4 A seguir explico o uso do termo linha.

5 A palavra toque é utilizada para designar diferentes coisas, além dos ritmos tocados ao tambor (exemplo, toque de Umbanda e toque de Quimbanda), utiliza-se também para designar o ritual (exemplo, "hoje tem toque", isto é, "hoje tem trabalho na terreira") e usa-se também esta palavra para designar algum trabalho feito com más intenções para outra pessoa, fala-se "fulano me tocou".

6 Membros da corrente que não incorporam e são responsáveis por servir os Guias.

7 Neste momento, estou fazendo uma generalização deliberada, pois tenho consciência que as pessoas têm diferentes visões, crenças e práticas sociais e religiosas.

8 Utilizo este termo assim como Guy Massart explica a "sociedade a qual se vive", explicando utilizar o termo "'sociedade" no sentido lato de realidade social existente para o agente, e não a uma unidade circunscrita do tipo Estado-Nação" (Massart, 2002: 306).

9 Chefe do Terreiro, mais conhecido como Pai de Santo, dentro das tradições de Candomblé e Batuque.

10 Apesar de, ultimamente, existirem ações de processos judiciais (como o sofrido pela mãe-de-santo Gisele Maria Monteiro da Silva, de Rio Grande/ RS - com base no Código Estadual de Proteção aos Animais) e o Projeto de Lei, articulado por políticos evangélicos e apoiado pelas sociedades de proteção aos animais, que buscava coibir a matança de animais nos cultos afro-brasileiros (Silva, 2007: 17). Para maiores informações sobre o tema ver: "Intolerância Religiosa - Impactos do neopentecostalismo no campo religioso afro-brasileiro", organizado por Vagner Gonçalves da Silva.

11 As traduções do trabalho de Rita Segato são de minha responsabilidade.

12 Podemos aqui chamar atenção também para o fato de o que é branco ser considerado bom, enquanto o que é negro ser considerado ruim.

13 Agradeço a Mário Maia por me chamar atenção às diferentes visões deste tema dentro dos próprios praticantes da Umbanda.

14 Assim são chamados os valores e ensinamentos religiosos próprios de cada terreira de Umbanda.

15 Sobre este assunto, o depoimento do Lom, já citado, explica tais aproximações devido às constantes perseguições, por parte da polícia, aos cultos afro-brasileiros. Renato Ortiz utiliza esta mesma explicação em seu trabalho "A morte branca do feiticeiro negro".

16 Letra completa do ponto: "Seu Belzebú é um Exu tão formoso / Ele traz o seu garfo na mão / Se ele é filho de Quimbanda / Eu quero ver a incorporação". 
17 Palavra utilizada, no universo umbandista, para se referir aos túmulos. Letra completa do ponto: "Exu, Exu é de duas cabeças / Uma é satanás no inferno a outra é Jesus de Nazaré".

18 Este ponto de Quimbanda também é citado por Vagner Gonçalves da Silva em seu artigo: Entre a Gira de Fé e Jesus de Nazaré: Relações Socioestruturais entre Neopentecostalismo e Religiões Afro-Brasileiras. In: Intolerância Religiosa - Impactos do neopentecostalismo no campo religioso afro-brasileiro. Edusp. São Paulo: 2007.

19 Termo utilizado para dizer que estão protegidas e recebem ordens de alguma entidade.

20 Esses questionamentos que trago aqui, já foram realizados muitas vezes por mim ao Cacique e alguns membros da corrente, mesmo antes do início desta pesquisa.

21 Carmen se refere ao fato de não se fazer mais assentamentos com matança de animais.

22 Com este termo Carmen quer se referir às grandes Festas feitas para o Povo de Quimbanda, onde todos comem, fumam, bebem, dançam, cantam e se divertem. Além do uso de roupas decotadas e da grande energia sexual presente neste tipo de trabalho ritual devido ao fato de estas entidades serem próximas da gente e se utilizarem de todos os tipos de energias.

23 Este ponto de Zé Pelintra descreve bem como estas entidades são vistas pelos umbandistas, os "donos da malandragem": "De manhãzinha quando eu vô descendo o morro / a nêga pensa / qu'eu vô é trabalhá (repete o trecho) / mas é qu'eu levo meu baralho no bolso / meu cachecol no pescoço / e vô prá Barão de Mauá / trabalhá, trabalhá, trabalhá pra que? / malandro se eu trabalhá, eu vô morrê."

240 "ponto de escuta" é a metáfora do "ponto de vista", isto é, "a metaforização do conhecimento pelo olho e pela visão -, quero indicar que a posição do ouvinte (num campo profissional, no eixo geracional etc.) condiciona sua audição" (Travassos, 2005: 94).

25 Existem pontos da linha de Quimbanda que são proibidos de ser cantados no Reino de Luz, estes são vetados por fazerem referências a Zé Pelintra como traficante ou assassino.

26 Ponto cantado de Exu Caveira.

27 Dei-me conta disso quando fui visitar um cemitério com um amigo e este me disse que se sentia incomodado de estar lá dentro por lembrar que pode perder seus pais, pois estes possuem idade avançada.

28 Mesmo sendo Catacumbas, no Reino de Luz estas entidades são chamadas desta forma: Sete Catatumbas.

29 Hoje vejo como a minha criação em escola católica, apesar de minha familia não praticar nenhuma religião, influenciou minhas ideias religiosas.

Renata Gomes, cantora e pesquisadora, é Bacharel em canto pela Universidade Federal de Pelotas e Mestre em Música pela Universidade Federal do Rio de Janeiro. Pesquisa religiões afro-brasileiras, possui diversos trabalhos apresentados e publicados em congressos nacionais e internacionais e atualmente é funcionária do CAPS-Encruzilhada do Sul (Centro de atenção psicossocial), onde ministra oficina de música. 